\title{
Visualizing the Victorian Christmas: Evolving Iconography and Symbolism in the Wake of Nineteenth-Century Commercialism
}

\author{
By Hilary Raats
}

The aesthetic of the Victorian Christmas is one that has enjoyed an enduring popularity well into the twenty-first century. Not only does it continue to enchant the celebrants of Christmas in their domestic lives, dictating certain traditions and styles of decoration, but it has left a continuing legacy in the commercial world. In 1989 when Lord \& Taylor, the oldest luxury department store in North America, decided on a Victorian theme for their holiday decorations, the vice president of visual merchandising Alan Petersen explained, "It has to do with nostalgia, with people wanting nice times. It also suggests a sense of quality craftsmanship: something that will last." The popularity of the Victorian Christmas is one thing that certainly has lasted, which then begs the question: why? Is, as Petersen suggests, the connection between Victoriana and Christmas a matter of nostalgia? If that is the case, then how and why is the nineteenth century still so accessible to the twenty-first century audience as to warrant such a sense of nostalgia? Perhaps the endurance of the Victorian Christmas in our collective memory can be partially attributed to the surviving imagery that the Victorians themselves produced through print media. This standardized imagery, which was produced as a direct result of commercialism, not only preserves the idealized Victorian Christmas in the minds of the twenty-first century audience, but helped to revolutionize the traditions and celebration of Christmas in England in the first place.

The English Victorian Christmas is responsible for lending many of the now quintessential traditions and practices to the modern twenty-first century Christmas celebration. Very much reflective of the rapid social and economic changes of the nineteenth century, the Victorian Christmas developed quite suddenly, within the span of about fifty years, and revolutionized the holiday. However, merely recognising that the celebration of Christmas underwent a rapid transformation in Victorian England does not help illuminate the major imperatives for such a significant shift. So, why did the English Victorians begin to celebrate Christmas differently? To answer this question, this essay will explore a particular facet of the Victorian Christmas, and that is the commercialization of the holiday. One consequence of nineteenth-century industrialism was the widespread availability of commercial products, which were marketed to consumers through seasonal advertisements at Christmastime. These advertisements, whether in print or in attractive display windows, capitalized on the "season of 
giving" by persuading the public to participate in the holiday by making material purchases. The practices of gift giving, feasting, and visiting friends and family at Christmas certainly existed in one form or another prior to the 1830s, but staples of the modern Christmas such as sending Christmas cards, bringing children to "Santa's Grottoes" in shopping centres, or even purchasing commercially available gifts, emerged only in the mid-to-late nineteenth century. Many aspects of Christmas that are now considered traditional were actually products of Victorian modernity. As a consequence of commercialization, some English traditions and customs, specifically the way in which Christmas was privately and publicly celebrated, changed. It is the thesis of this essay that the evolution of Christmas festivities can largely be attributed to the marketing of the holiday to the Victorian audience. In other words, because of the materialistic representation of Christmas put forth by nineteenth-century advertisers, concepts of celebration gradually began to evolve, giving rise to the quintessential Victorian Christmas.

The English Christmas celebrations of the early nineteenth century lacked many conventions that are now standard in the English-speaking west. There were no Christmas cards, no Christmas trees, and there was no collective effort to decorate public space. While the private home might be decked with boughs of evergreen, the shopping districts would have looked much the same as the rest of the year, reflecting no effort to appeal to a market of Christmas shoppers that did not yet exist. That being said, there were certainly continuities of past Christmas celebrations that are important to keep in mind. However, many of the pre-existing elements of the early nineteenth-century Christmas were not actually English, and consequently, the Victorians cannot rightly take credit for their popularization. For example, although there was an expansion of seasonal charity in the nineteenth-century, perhaps best exemplified in Dickens' Christmas Carol, Christmastime had a longstanding tradition of almsgiving associated with Christian morality outside of England. ${ }^{2}$ Even pagan traditions influenced certain festive practices and beliefs. The very date on which Christmas is celebrated, December 25, was instituted by Pope Julius I in $350 \mathrm{AD}$ in order to align with the birth of the Roman-Syrian sun god Mithras. ${ }^{3}$ The pragmatic Victorians also adapted the Scandinavian mid-winter tradition of the Yule Log, burning it for 12 hours rather than the grueling full 12 days. ${ }^{4}$ Even the ostensibly English practice of wassailing, a mode of reciprocal carolling with alcohol, predates the Norman Conquest and etymologically implies that it is of Saxon origin, and so cannot be confidently attributed to the English. ${ }^{5}$ As this essay will go on to discuss, the Christmas Tree, which was so 
well-loved by the Victorians, was in fact a German import popularized by Prince Albert and the royal family in the 1830 s. Ultimately, the Victorians cannot take full credit for many of the practices and beliefs associated with Christmas, importing most traditions from the continent and from pre-existing religious beliefs, which begs the question: what exactly makes the English Victorian Christmas so iconic?

The celebration of Christmas in nineteenth-century England undoubtedly incorporated many foreign and religious elements imbued over the course of centuries. It might be argued, then, that until the Victorian period, Christmas as a cultural practice was one which England had merely imported and subsumed. One of the most well known diarists in English history, Samuel Pepys, recounted his 1664 Christmas Day, reporting, "Up (my wife's eye being ill still of the blow I did in a passion give her on Monday last) to church alone, where Mr. Mills, a good sermon. To dinner at home, where very pleasant with my wife and family [sic]." ${ }^{6}$ Following dinner, Pepys went to visit a Sir W. Batten and then to another church service, finally returning home, “...looking over and setting in order my papers and books, and so to supper, and then to prayers and to bed."7 Elements of the modern Christmas are here in Pepys' account: attending church, enjoying a family meal, and visiting friends. However, Pepys fails to represent any excitement or particular pleasure associated with modern incarnations of the holiday, and the account all but neglects his children, focusing rather on adult joviality. He clearly observes the prescribed Christmas traditions, but it is a muted, mundane affair compared to later Victorian expectations of Christmas Day. It seems no coincidence that the English only really began to express enthusiasm for Christmas when it began to appear more and more frequently in print. In other words, when those in control of print media, particularly advertisers, began to use Christmas as a way to boost retail by producing a particular image of the holiday, they veritably changed the perception of what Christmas was supposed to look like and how it should feel. Commercialism revolutionized the aesthetic of the English Christmas.

One of the most iconic symbols of the Victorian Christmas, the Christmas tree, was one of the many traditions imported from the continent. Famous authority on the Victorian Christmas, Charles Dickens, once described the Christmas tree as "that pretty German toy." fashion of the Christmas tree was one that had crept into England in the very early nineteenthcentury, but which was primarily reserved by the elite. As early as 1800 Dr. John Watkins, a biographer of German-born Queen Charlotte, observed a yew tree at Windsor during a Christmas 
party, as it was customary for the wealthy to host and feed the poor at Christmas. The yew tree was reportedly decorated with dried fruit and almonds and lit candles. ${ }^{9}$ However, the popularity of the Christmas tree would not spread for nearly half a century. Despite clearly being present in England in 1800s thanks to Queen Charlotte, it was only after an illustration of the royal family gathered around their Christmas tree was released in the December 1848 issue of the Illustrated London News that the trend caught fire.

The impact of the illustrated Christmas Tree on English celebrations was significant and, as a result of its influence, the English began to construct a new Christmas narrative for themselves. Two years after the release of the famous illustration of the royal family, Charles Dickens published a short story titled "A Christmas Tree" which follows the nostalgic narrative of an elderly man reminiscing about the Christmases of his childhood. In the story, a Christmas tree fancifully appears in the home of the nameless narrator, and between the boughs of evergreen branches, he sees several childhood memories, of toys he received and stories he heard at Christmas, which he proceeds to thoughtfully examine. The story concludes with the departure of the tree. The narrator adds, as one of his final thoughts, "Encircled by the social thoughts of Christmas time, still let the benignant figure of my childhood stand unchanged!" 10 This is a charming story, but there is a glaring problem with it: the tradition of the Christmas tree had entered the public consciousness no more than two years before its publication due to the illustration of the tree at Windsor Castle, so there is an obvious discrepancy between the old age of the narrator and the new popularity of the tree. Either Dickens is rewriting the history of English Christmas to accommodate the tree, or, he is predicting the future significance of the tree within the experiences and memories of Victorians. Either way, Dickens touches upon a thought provoking theme, which is the widespread and visceral acceptance of the Christmas hype propagated through print media.

As iconography from the Victorian period shows, Christmas was not only a time to celebrate the birth of Christ, but also a time of good-humour and secular gaiety. It is the nineteenth-century invention of the Christmas card that perhaps best exemplifies the significance of visuals to the Victorian Christmas. A feature of Christmas that is now often taken for granted, the reciprocal practice of sending Christmas cards only became accessible beyond high society with the technological innovation of chromolithographic printing and with modern reforms to the postal service, namely the Uniform Penny Post. ${ }^{11}$ The Victorians quickly took advantage of these 
new Christmas cards, relying on the decorative illustrations to communicate ideas with the recipient as much as they relied upon the personal inscription within the card. As historian Neil Armstrong explains, "From the 1870s, Christmas cards played an important role in the evolution of the modern signifiers of Christmas for the English, though during the nineteenth-century the thematic range of images displayed on the cards was indicative of an unstable and unsettled iconography in the process of negotiation in a new mass commercial age." 12 Before the $1840 \mathrm{~s}$, England lacked a standardized visual representation of Christmas, so the Victorians were essentially experimenting with imagery, selecting the iconography that would serve to represent their collective conceptualization of Christmastime.

Although many cards bore the type of imagery we still associate with Christmas, such as evergreen wreaths, sprigs of holly and mistletoe, and Christian scenes, an intriguingly large sample of Victorian cards lack "traditional" and religious themes. One blurb advertising the sale of Christmas cards found in an 1877 issue of the Illustrated London News reads:

Our page Engraving, from drawings by Mr. George Cruikshank, junior, exhibits a collection of grotesque and humorous devices, bearing reference to the customs of this festive season, and suitable by the form and size of the drawings, if not by their spirit and character, to appear on these missives of personal greeting which people send by post to their acquaintance in the last week of the year. ${ }^{13}$

The Mr. George Cruikshank (1792-1878) mentioned here was a Victorian caricaturist, and his art is stylistically not what one might associate with the type of sentimental Christmas cards that are in vogue today. The Victorians of the 1870s were clearly using Christmas cards as a way to engage in forms of friendly exchange, but the iconography of these cards was not necessarily "Christmassy." The provocative title of one BBC News article, "Frog Murder and Boiled Children: 'Merry Christmas' Victorian Style," does not disappoint, treating readers to several Victorian Christmas cards preserved by the Library of Birmingham that feature a number of scenes probably unfamiliar to the modern audience. The illustrations include, but are certainly not limited to, an anthropomorphic frog stabbing and robbing another frog, a child wishing the reader a "Christmas Greeting with Love" with a facial expression contorted from the pain of being submerged in a pot of boiling tea, and even a mouse riding a lobster steed. Another illustration, which bears the image of a monkey painting the portrait of a dog, begs the question: what were these types of Christmas cards tying to say? What messages were being sent? 
Stephanie Boydell, the curator of special collections at Manchester Metropolitan, argues, "The Victorians had a different idea to what Christmas was about - not particularly Christian, but a time of good humour." 14 This explanation speaks for the secularization of Christmas. The Christmas card, which was only made available to the mass market through commercialism, in itself began to proliferate secular and non-traditional themes through visual imagery.

Often the subject of Christmas card illustrations themselves - both in the sentimental and satirical styles - children also experienced a newfound connection to the holiday during the Victorian period. The developing concept of "childhood" in the nineteenth-century is perhaps partially responsible for the association between children and Christmas, and the motivation behind the popularization of store-bought toys. Certainly to some degree, children became symbols of the Christmas season. In Dickens' Christmas Carol, the reader is meant to form an emotional connection with Tiny Tim, and the personifications of charity (Ignorance and Want) are notably depicted as beggar children. At the same time, however, advertisers were reinforcing the importance of Christmas to the child in order to capitalize on such emotional connections. As one writer states, "As Dickens had recognized in his Christmas Books, children were effective ploys for getting the public's attention. But they could consume only by proxy." ${ }^{15}$ Certainly before the nineteenth-century, Christmas centred on religious observances and adult socialization, as the earlier account from Pepys illustrates. The later appearance of children in seasonal advertisements therefore should not be attributed to an innate connection between children and Christmas, but rather as the result of an emotional marketing technique aimed at parents to promote spending on seasonal gifts.

Even before the nineteenth-century, gift giving had always been an important aspect of the Christmas season. Commonly, however, much of the gift giving was directed towards the poor as a part of the prescribed Christian charity. And while the rise of print media, specifically newspapers, illustrated the culture of gift-giving at Christmas, before the nineteenth-century, it was often not with the intention of boosting sales, but instead publicising acts of elite generosity. During the Christmas of 1742 The Daily Advertise printed a thank you from the "poor prisoners of the Common side of his Majesty's prison of the fleet" to a benefactor who sent three "chaldrons" of coal. Ilana Krausman Ben-Amos, a social and cultural historian of early modern England, analyses this article, arguing, “...emerging newspapers played a special role in offering novel venues for promulgating and publicizing the prestige and esteem of those engaged in 
benevolent acts. ${ }^{, 16}$ As early as the eighteenth-century, newspapers were clearly printing articles that focused on the gift-aspect of Christmas, but as Krausman illustrates, it was done to honour and pamper the prestige of the gift-giver. In the next century, however, the idea of the Christmas gift was publicised in print media for an ulterior motive: to promote consumerism.

As late as the 1840s, the "Christmas advertisements" were primarily those for tickets to theatrical performances. Advertisements for dramas like Lyceum and various pantomimes abound in newspapers from the day. One blurb from an 1844 issue of the Illustrated London News states:

The approach of Christmas brings with it a temporary quiet in theatrical proceedings; that is to say, as regards the productions of new pieces, for, behind the curtain, every member of the establishment for the time being, from the authors down to the carpenters, is fully employed, in order that everything may be ready by 'Boxing Day.' And getting up a pantomime or fairy burlesque is no joke.... ${ }^{17}$

Forms of Christmas entertainment were widely popular during the Victorian period, and may even be viewed as a type of conspicuous consumption. It is hardly surprising that the middling classes, with the increasing emergence of disposable incomes in family homes, might indulge in a few extra luxuries at Christmas. By validating their economic statuses through participation in the fashionable activities advertised in the newspapers, the middling classes engaged with and shaped popular culture. Even today, pantomimes enjoy an enduring popularity in England, and the image of brightly painted wooden soldiers with big white teeth have become a staple of the modern Christmas tradition as every major ballet company annually puts on a production of the Nutcracker. It should not be surprising, then, that even as late as the 1850s Christmas advertisements focused on social aspects of the season, especially buying tickets to various forms of public entertainment. In the following decades, however, the wealth of advertisements in the newspaper would shift to the promotion of commercial goods. A marked increase in the number of advertisements explicitly promoting goods as "Christmas gifts" suggests that it was during the later Victorian period that advertisers began to realize the marketability of the season.

By the 1870s, it was fairly standard for brief textual advertisements to advertise certain goods as being particularly suited for Christmas gifts. For example, in the Christmas 1877 issue of the Illustrated London News, Parkins \& Cotto's placed a textual advertisement boasting "10,000 Christmas Presents," which proceeded to list a number (falling quite short of 10,000) of 
gifts available for purchase, including dressing-cases, electro-plated goods, music boxes, magic lanterns (with slides), ivory paper knives, books for "juveniles," graphoscopes, and family bibles. ${ }^{18}$ Not many advertisements offered such a detailed description of their goods, but even this detailed Parkins \& Cotto's ad lacks one striking feature: illustrations. By the late 1880s, however, Christmas advertisements were spread thickly across the Illustrated London News and many, though not all, included illustrations. In 1888, the Illustrated London News featured a spread of "Mappin \& Webb's Artistic and Useful Christmas Presents," filled will illustrations of fine spoons, a set of ornate nut-crackers and picks, a sugar bowl with tongs, and many other pieces of silver tableware. ${ }^{19}$ Advertisement of "Negretti \& Zambra's Christmas Presents" included "useful and ornamental" ivory opera glasses for ladies and leather-bound field glasses for gentlemen, accompanied by the image of a pair of binoculars. ${ }^{20}$ The image of a finely dressed woman stands under the header "Fashions for the Season" placed by the Peter Robinson department store chain. ${ }^{21}$ A selection of ornately drawn pocket watches advertised by Benson's, including "£10 lever watches," promised Christmas shoppers that "Purchasers in all Parts of the World using these Watches testify to their Strictly Accurate Timekeeping Qualities." ${ }^{22}$ Why retail businesses decided to start adding illustrations to their advertisements in the 1880s probably has to do more with innovations in printing technology rather than anything, but that line of inquiry is not terribly relevant. What is relevant is the impact that these visually-based advertisements had on the public at Christmas. By exciting retail with their visually stimulating advertisements, print media merged notions of celebration and commercialism, producing a collective understanding of Christmas in England that was based on materialism in addition to pre-existing notions of charity and merriment.

It is important to recognize that not all Christmas advertisements took place in print. Especially with the relatively recent advent of the department store, the Victorian period witnessed the liberation of Christmas decorations trapped within the domestic space as they spread into the public space. These decorations provided a seasonal incentive to visit shopping districts and, consequently, to spend money. In other words, the shopkeepers and department store owners created a spectacle out of Christmas in order to encourage business. This invasion of the public space was not without controversy, however. In 1875 William Whiteley, founder of London's first department store, Whiteleys, placed a Christmas flag in Westbourne Grove. In response, Henry Walker, an editor of the Bayswater Chronicle, criticized the flag's presence. 
One historian describes the conflict, saying, "Walker charged that Whiteley's flag inhibited the 'liberties' of public thoroughfares and that such vulgarities, 'typical of Broadway in New York,' were inappropriate adornments for English streets. Walker patriotically... hailed the flag's removal as a national victory and asserted, 'We don't want to Americanize the Grove.",23 Innocuous as they may seem to the modern audience, Christmas decorations of the nineteenthcentury became a visual representation of the internal conflicts resulting from the rapidly evolving consumer culture in England. Ultimately, by the end of the Victorian period, Christmas represented a pinnacle of the retail year as much as an eminent date within the Christian calendar.

Even with all advances to modern retail, the Christmas experience was not uniform for all Victorians. In contrast to the commercial spectacle of Christmas in the urban space, for example, those living in rural areas were more likely to decorate their homes with hand crafts and locallysourced evergreen. If natural resources were not as accessible to city-dwellers as they were to the rural folk, other commercially available goods made up for it. One advertisement from an issue of the 1853 Lady's Newspaper and Pictorial Times offered its London customers the opportunity to send fish from the city to "any part of the Kingdom," using the slogan, "To the lovers of fish. Christmas Presents for country friends. ${ }^{24}$ This pleasantly peculiar advertisement implicitly tells the reader that Christmas fare was not accessible to all people in all areas. Such limitations to trade and retail undoubtedly imparted some degree of regionalism to the English Christmas celebration that is often forgotten in the retrospective imagination.

Purchasing power and the availability of specific goods or imported ingredients became very important to the concept of the Victorian Christmas. Even certain foods that bore longstanding associations with Christmas developed deeper symbolic values due to the appearance of Christmas in popular culture. During the Christmas of 1860, Charles Edward Smith, a surgeon employed on a whaling vessel, recorded how eager he had been for his Christmas dinner to end, despite being treated to the traditional Christmas fare of plum pudding in addition to the usual ration of boiled salt beef and a portion of tripe. According to Smith, "We ate our Christmas dinner almost in silence, each man's mind being occupied with gloomy thoughts of home, families, and friends," adding, “... I was glad when 'twas over, it seemed such a horrible mockery of the spirit of an English Christmas." ${ }^{25}$ These sailors, far from home, demonstrate a clear notion of what defined the "spirit of an English Christmas," although their attempt to 
replicate the Christmas dinner ultimately fails without their families. Still, the fact that these sailors centred their dinner around a plum pudding suggests a collective understanding of Christmas symbolism. Due to the preservative properties of plum pudding (and the fact that much to the benefit of sailors and the predominantly stove-less middle classes alike - this type of pudding does not require being cooked in an oven), it is actually quite a practical dessert to store on a ship, but it hardly seems likely that Smith and his companions chose to pair their Christmas meal with plum pudding because of its practical qualities. Rather, Smith and his companion sailors demonstrate a sentimental relationship with their meager Christmas dinner. Various recipes for plum pudding date back to the medieval period, but the stodgy dessert became reinvigorated by the Victorians and their importation of sugar and dried fruits from the farreaches of the empire. In 1845, Eliza Acton became the first known person to record the recipe as "Christmas Pudding" in her bestseller Modern Cookery for Private Families. ${ }^{26}$ An element of Victorian playfulness was also added to nineteenth-century plum pudding recipes, which began to include certain tokens with symbolic values. One historian explains, "After the family had all participated in stirring the batter, the mother would secretly drop in a thimble (for spinsterhood), a ring (for marriage), a coin (for wealth), a miniature horse (for good luck), and various other items to be found by the diners during the Christmas feast itself." ${ }^{27}$ When Smith expressed dissatisfaction with the Christmas dinner, it was not due to the meagreness of the fare itself, but due rather to the melancholy caused by the complex symbolic value of the dining experience on a personal level.

Not only were the goods and ingredients necessary to produce the perfect Victorian Christmas not geographically available to everyone, but the socio-economic disparity in nineteenth-century England also greatly influenced and in fact limited the Victorian Christmas celebrations, which made it impossible for everyone to attain the idealistic holiday perpetuated through contemporary imagery. Extra seasonal purchases were not something that were necessary to the celebration of Christmas, and yet people from all levels of society chose to partake in the increasing materialism of the holiday to the best of their economic ability. Whereas the elite dined on peacock and swan, the relatively inexpensive American turkey became a seasonal staple of the middle-class Christmas meal. As Victorian sensation Mrs. Beeton wrote, "A Christmas dinner with the middle classes of this empire, would scarcely be a Christmas dinner without its turkey; and we can hardly imagine an object of greater envy than is 
presented by a respected portly pater familias carving, at the season devoted to good cheer and genial charity, his own fat turkey, and carving it well." ${ }^{28}$ Roast turkey was not just a seasonal indulgence for the Victorians, but a visceral component of the Christmas celebration. They attached to the turkey notions of frivolity, abundance, good cheer, and family. As with other forms of holiday shopping, buying a turkey at Christmas was not just purchasing a meal, rather it was buying into and perpetuating an idealized version of the holiday, which the Victorians themselves had created.

As strange as it may seem, the Victorian Christmas was not really a traditional affair at all. Certainly, Christian beliefs and newly imported European practices culminated in what many in the western world now consider the "traditional" Christmas celebration, but in the Victorian period, many of these "traditional" practices were in fact novel innovations. It is no coincidence that the emergence of the Victorian Christmas coincided with the second Industrial Revolution. The expansion of commercialism during the nineteenth-century bled into aspects of culture and celebration, producing a new conceptualization of Christmas that was steeped in both tradition and Victorian modernity. Due to the success of its colonies and industries, mid-to-late nineteenth-century England enjoyed a healthy economy which in turn produced a bankable mass market. The middle class finally had disposable income to spend on frivolity, and commercial goods were more accessible than ever. It can perhaps be considered a stroke of advertising genius that Christmas became a way to encourage consumers to spend some extra money once a year. As a direct result of commercialism, the look of Christmas in the secular sphere began to evolve as new iconography emerged, as Christmas advertisements became more prevalent, and as shops began to draw customers in with seasonal decorations. Christmas was no longer relegated to purely domestic or religious spheres, but was advertised for public consumption and consequently was able to develop new symbolic and iconographical meanings within England's secular domain. Within its capacity as a product of the consumer spectacle, the Victorian Christmas produced an aesthetic with resonating symbolic value, which endures within public consciousness to this day.

\section{NOTES}

\footnotetext{
${ }^{1}$ Florence Fabricant, "Victorian Era: Holiday Images for all Times," New York Times, November 29, 1989, Regional Business News. EBSCOhost (accessed November 6, 2015).
} 
${ }^{2}$ Neil Armstrong, Christmas in Nineteenth-Century England (Manchester: Manchester University Press, 2010), 119.

${ }^{3}$ Jonathan Green, Christmas Miscellany: Everything You Always Wanted to Know about Christmas (New York: Skyhorse Publishing, 2009), 12.

${ }^{4}$ Ibid, 119.

${ }^{5}$ Joanne Asala, Celtic Folklore Cooking (St. Paul, Minnesota: Llewellyn Publications, 2004), 42.

${ }^{6}$ Samuel Pepys, Diary of Samuel Pepys (1633-1703), eds. Mynors Bright, Baron Richard Griffin Braybrooke, and Henry Benjamin Wheatly (London, NY: G. Bell, 1893), 295, https://archive.org/details/cu31924070674977

${ }^{7}$ Ibid. (accessed November 10th, 2015).

${ }^{8}$ Charles Dickens, “A Christmas Tree,” in Household Words 11, no. 39 (December 21, 1850): 289, http://www.djo.org.uk/ (accessed December 3, 2015).

${ }^{9}$ Christopher Christie, The British Country House in the Eighteenth Century (Manchester: Manchester University Press, 2000), 300.

${ }^{10}$ Dickens, "A Christmas Tree," 295.

${ }^{11}$ Armstrong, Christmas in Nineteenth-Century England, 31.

${ }^{12}$ Ibid.

${ }^{13}$ Illustrated London News, The. Volume LXXI, no. 2008, December 22, 1877 (London: George C. Leighton, 1878), 587.

${ }^{14}$ Bethan Bell, "Frog Murder and Boiled Children: 'Merry Christmas' Victorian Style," BBC News, 21 December 2015, http://www.bbc.com/news/uk-england-34988154 (accessed January 4, 2016).

${ }^{15}$ Thomas Richards, The Commodity Culture of Victorian England: Advertising and Spectacle, 1851-1914 (Stanford: Stanford University Press, 1990), 241.

${ }^{16}$ Ilana Krausman Ben-Amos, The Culture of Giving: Informal Support and Gift-Exchange in Early Modern England (New York: University of Cambridge Press, 2008), 226.

${ }^{17}$ The Illustrated London News, "The Theatre," vol. V, December 14, 1844 (London: William Little, 1845), 378.

18 The Illustrated London News, vol. LXXI, December, 1877 (London: George C. Leighton, 1878), 576.

${ }^{19}$ The Illustrated London News, vol. XCIII, December 1, 1888 (London: Ingram Brothers, 1889), 659.

${ }^{20} \mathrm{Ibid}, 667$.

${ }^{21}$ Ibid.

${ }^{22}$ Ibid., 693.

${ }^{23}$ Erika Diane Rappaport, Shopping for Pleasure: Women in the Making of London's West End (New Jersey: Princeton University Press, 2000), 39.

${ }^{24}$ Lady's Newspaper and Pictorial Times, vol. XIV, no. 364, December 17, 1853 (Center for Research Libraries), 378, http://catalog.crl.edu/record=b2854645 S1 (accessed February 29, 2016).

${ }^{25}$ Charles Edward Smith, From the Deep of the Sea; Being the Diary of the Late Charles Edward Smith, M.R.C.s, Surgeon of the Whale-ship Diana, of Hull (London: A. \& C. Black, 1922), 138-9.

${ }^{26}$ Harlan Walker, Oxford Symposium on Food and Cookery, 1990: Feasting and Fasting (London: Prospect Books, 1991), 36.

${ }^{27}$ Andrea Broomfield, Food and Cooking in Victorian England: A History (Westport, CT: Praeger Publishers, 2007), 150.

${ }^{28}$ Isabella Beeton, Mrs. Beeton's Household Managements (Ware, Hertfordshire: Wordsworth Editions, 2006), 486. 